\title{
Library literature in non-library
}

\section{publications}

\author{
By Becky Kornegay
}

Reference Librarian

Western Carolina University

\section{We need to reach a larger audience.}

$\mathbf{L}$

ibrary Literature 1989 lists more than 700 articles about academic libraries. That includes only articles listed under the heading "College and University Libraries," not those assigned related headings such as "Bibliographic Instruction" or "Junior and Community College Libraries." Many of the articles sound worthwhile, even thought provoking: "Bibliographic Instruction and Critical Thinking," "Teaching Academic Integrity," "Information Support for Academic Administrators." Of course, it is impossible to judge quality from the titles, but one thing is unquestionable: academic librarians publish a lot of articles about the library in the university setting.

But who is reading the journals in which these articles appeared: $R Q$, Research Strategies, College and Research Libraries? Librarians, for the most part. Academic librarians are doing a lot of preaching to the choir. Of course, the ideas which we present in our journals are often interesting to other librarians, but consider how useful and effective much of our writing could be if it were read by another academic audience-the college teaching faculty.

By working at the reference desk in a college library, librarians see students and their coursework from a perspective unavailable to professors. As John Lubans, Jr., put it in his column, "Library Literacy" ( $R Q$, Winter 1988), librarians see the process whereas professors see only the outcome. Because of our unique perspective, our ideas about "the process" - critical thinking, information-seeking skills, research assignments that work (or don't)—would be not only valuable to teaching faculty but new to them as well.

How can we get our ideas across to teaching faculty? ACRL past president William Moffett recommends liaison activity, characterized by participation in non-library professional and scholarly organizations. That means, in the case of publication, submitting our articles not only to library journals, but also to journals devoted to higher education and pedagogy at the college level.

There are about fifty such journals, which can be identified through Education Index, Magazines for Libraries, and (most useful) Education Journals and Serials: an Analytical Guide. These journals fall into three categories. The first, which includes Change and The Chronicle of Higher Education, are issue-oriented journals which report on news and trends in higher education. The second category comprises journals such as College Teaching and The Teaching Professor, which focus on teaching practice across the disciplines. Journals which address the pedagogy of a specific subject (Teaching of Psychology, Journal of Geological Education) comprise the last and largest category.

Some journals have particular columns or sec- 
tions which are appropriate for library-oriented articles. For example, College Composition and Communication has "Staffroom Interchange," essays $1,000-3,000$ words long which, according to the journal itself, "describe a specific instructional or administrative practice, or explore broader issues of theory and practice in composition." The Journal of Economic Education describes its "Economic Instruction" section as including "articles, notes, and communications describing innovations in pedagogy, hardware, materials, and methods for treating traditional subject matter."
Other journals, in addition to those listed above, would include Community, Technical, and Junior College Journal, Engineering Education, Journal of Education for Business, Journal of Nursing Education, The Physical Educator, The History Teacher, Teaching Sociology, and Speech Communication Teacher. The main criteria for consideration would be that the journal be a likely vehicle for articles about the place of the library in higher education and that it have as its target audience college teaching faculty - the audience we need to reach.

\section{Washington State Newspaper Project completed}

The Washington State Newspaper Project has achieved its major goals: to locate and preserve all newspapers published in the state, enter information about those 2,200 newspapers into a national database, and microfilm the newspapers for availability through interlibrary loan. Over 500 newspaper titles and more than 1.5 million newspapers were preserved. Fifty-six newspapers were identified which were unknown before the project began.

The Newspaper Project was administered by the Washington State Library. State librarian Nancy Zussy says it will have a monumental impact on the preservation of Washington State's heritage and history. She points out that in many cases the only extant records of a community and its heritage were its old newspapers, which were often damaged, decaying, or even unknown.
Project director Gayle Palmer reports that one important result of the project is the production of the Washington State Union List of Newspapers on Microfilm, which provides information on every Washington State newspaper published since 1853. It lists which libraries in Washington hold copies of the newspapers and whether the microfilm can be borrowed. Published by the Washington State Library, the union list is now available at cost. Microfilm is available on interlibrary loan from the Washington State Library.

Funding for the project came from all sectors of the state and from individuals, newspapers, publishers, and grants. Over $\$ 97,000$ in local funds were raised, which were matched by the National Endowment for the Humanities. Governor Gardner completed funding for microfilming the newspapers with $\$ 30,000$ from his emergency fund.

\section{OCLC announces award for reference librarianship}

A $\$ 1,000$ cash prize will be given by OCLC to a librarian who best demonstrates what it takes to serve on the front lines of reference services. The first OCLC "On the Front Line" award will be presented to such a librarian at the Online/CDROM 1991 conference.

The award will be given to the individual who, during the course of a typical work day:

- makes effective use of electronic reference products in providing reference services to patrons;

- best integrates electronic reference tools into the flow of traditional reference services;

- best explains to patrons reference options, including online public access catalogs (OPACS), local area networks (LANs), CD-ROMs, online databases, books, and directories;

- demonstrates knowledge, creativity, good humor, and "goes the extra mile" for patrons.

A panel of three to five judges will decide the award based on information provided in the applications. Judges will be selected for their prominence and credibility in the electronic reference arena. Their names will be announced in February 1991.

Nomination information and applications may be obtained by writing to: OCLC, Attn: Reference Services Division, MC 236, 6565 Frantz Road, Dublin, OH 43017-0702. Deadline for nominations is July $31,1991$. 